\title{
7
}

\section{Where People Live and Move in Deltas}

\author{
Ricardo Safra de Campos, Samuel Nii Ardey Codjoe, \\ W. Neil Adger, Colette Mortreux, Sugata Hazra, \\ Tasneem Siddiqui, Shouvik Das, D. Yaw Atiglo, \\ Mohammad Rashed Alam Bhuiyan, \\ Mahmudol Hasan Rocky and Mumuni Abu
}

\subsection{Introduction}

All regions of the world through the twentieth century have undergone absolute transformations in peoples' lives: they live longer, have fewer children, and are much more likely to live in towns and cities. While

R. Safra de Campos $(\bowtie)$. W. N. Adger · C. Mortreux

Geography, College of Life and Environmental Sciences,

University of Exeter, Exeter, UK

e-mail: R.Safra-De-Campos@exeter.ac.uk

S. N. A. Codjoe · D. Y. Atiglo · M. Abu

Regional Institute for Population Studies, University of Ghana,

Legon-Accra, Ghana

S. Hazra $\cdot$ S. Das

School of Oceanographic Studies, Jadavpur University, Kolkata, India

T. Siddiqui · M. R. A. Bhuiyan · M. H. Rocky

Refugee and Migratory Movements Research Unit, University of Dhaka, Dhaka, Bangladesh 
these are individual decisions, it is now commonly understood that the structural drivers of such profound changes lie in economic opportunities, culturally shared expectations, access to health technologies and levels of education (Lutz et al. 2017). Regions and countries experience so-called demographic transitions of lower mortality especially infant mortality, followed by lowered total fertility rates (TFR) after a time lag, with these two combining to produce rapid population growth followed by stabilisation, population ageing and sometimes decline. The current global aggregate population of more than seven billion may stabilise over the incoming decades, but the timing of this stabilisation is not discernible in advance as it is driven by underlying drivers.

Scientific synthesis of the underlying drivers for future population shows that the outcomes that matter are on levels of fertility, mortality, migration and education, especially female education rates and quality. Analysis of the Shared Socio-economic Pathways descriptions of the future by Samir and Lutz (2017) and Abel et al. (2016) show that scenarios involving sustainability priorities, universal education and human rights result in projections of global populations around seven billion by the end of the twenty-first century. At the other extreme, future scenarios with significant and persistent poverty, population momentum, less access to education and fewer health gains, can produce global populations of greater than twelve billion by the end of the century.

A related major Anthropocene trend is in health outcomes: essentially sustained improvements in longevity and positive health across many parts of the world, despite challenging environmental conditions. McMichael (2014), for example, highlights life expectancy of more than 75 years in much of the world including in cities in countries with rapid economic growth; gains coming from sanitation, hygiene and maternal education. Limiting factors for life expectancy are currently principally non-communicable diseases such as cancers and heart and lung diseases associated with sedentary lifestyles, exacerbated by exposure to pollutants (McMichael 2014).

So why is population health, as manifest in greater life expectancy, increasing when ecosystem services are in decline and pollution exposure is increasing? This apparent paradox is explained in a number of 
alternative ways. On the one hand, well-being is not being reliant on the environment but principally on provisioning ecosystem services; availability of food production globally has increased substantially in the past half-century. Alternatively, health may be increasingly decoupled from environmental challenges, with urban living meaning populations are less exposed to environmental risks. Finally, as most population health research suggests, there is a significant time lag between environmental degradation and the impacts appearing in the overall health of populations (Whitmee et al. 2015). Hence McMichael (2014) and others suggest that there are looming crises and challenges to human health in the incoming decades, not least through accumulating toxic effluent in air, water and soil and through urban interfaces with climate change including exposure to heat and pollution interactions. So continued health and well-being gains from resource exploitation are not inevitable in the future, and adverse trends cannot be discounted.

The third major Anthropocene trend has involved the movement of whole populations towards urban settlement. Projections of global urban populations suggest around five billion people living in urban settlements by 2030, with an associated tripling of the global urban land area since 2000 (Seto et al. 2012). This increases the proportion of global populations living in urban areas to be greater than the current $55 \%$, with growth concentrated in the present mega-cities, many of which are in coastal and delta areas, especially in Asia. Much of this growth occurs through migration towards urban settlements. Migration brings benefits to those moving both in terms of avoiding risks in source areas and, more importantly, providing economic, social and educational opportunities in destination areas. Individual decisions involve complex interactions between families, perceptions of opportunity and risk, and social expectations. However, at the aggregate level, the movement of many millions of people creates challenges for both rural source areas losing human capital, and for the sustainability of urbanisation processes, as illustrated in deltas (Szabo et al. 2018).

Deltas reflect these global trends and challenges. Deltas and coastal areas in general are in net population growth due to migration flows over the past half-century. They are areas where people have lived in 
large numbers since the advent of intensive agricultural production and have been the sites of the growth of major cities over the past century. This chapter therefore examines the demographic and mobility dimensions of development and the prospects for flourishing and sustainable futures in deltas. It does so by examining the dynamics of current and future populations in three deltas located in South Asia and West Africa-the Ganges-Brahmaputra-Meghna (GBM) which is comprised of the India Bengal and the Bangladesh sections, Mahanadi and Volta (Chapters 2-4). Given major changes in the physical and ecological dimensions of low lying coastal areas including deltas projected for the future (Brown et al. 2018), the chapter examines potential interventions to protect populations in place and to assist the movement of people away from environmental risks and harm.

\subsection{Population Dynamics of Deltas}

At the turn of the century around seven per cent of the world's population lived in deltas (Ericson et al. 2006). The proportion is likely to have increased since with the global phenomenon of the so-called drift to the coast. But population dynamics involve specific demographic processes such as population structures by age and sex, ongoing changes in the drivers of fertility, life expectation and mortality and migration. In addition, projections of sea-level change and rapid-onset hazards such as cyclones and flooding, exacerbate existing challenges for life and livelihoods of delta communities, as outlined in Chapter 6.

Demographic studies suggest that countries experience concomitant declining mortality and fertility levels typically associated with increasing life expectancy as they progress through the different stages of the demographic transition (Caldwell 2006; Dyson 2013). Intervening factors such as economic development and the quality of the biophysical environment influence the speed of such a transition. The majority of developing countries show this rapid demographic transition over the past 40 years associated with gradual improvement to sanitation, nutrition, access to health services and education. For example, the population structure of the coastal districts of Bangladesh (Fig. 7.1) based 


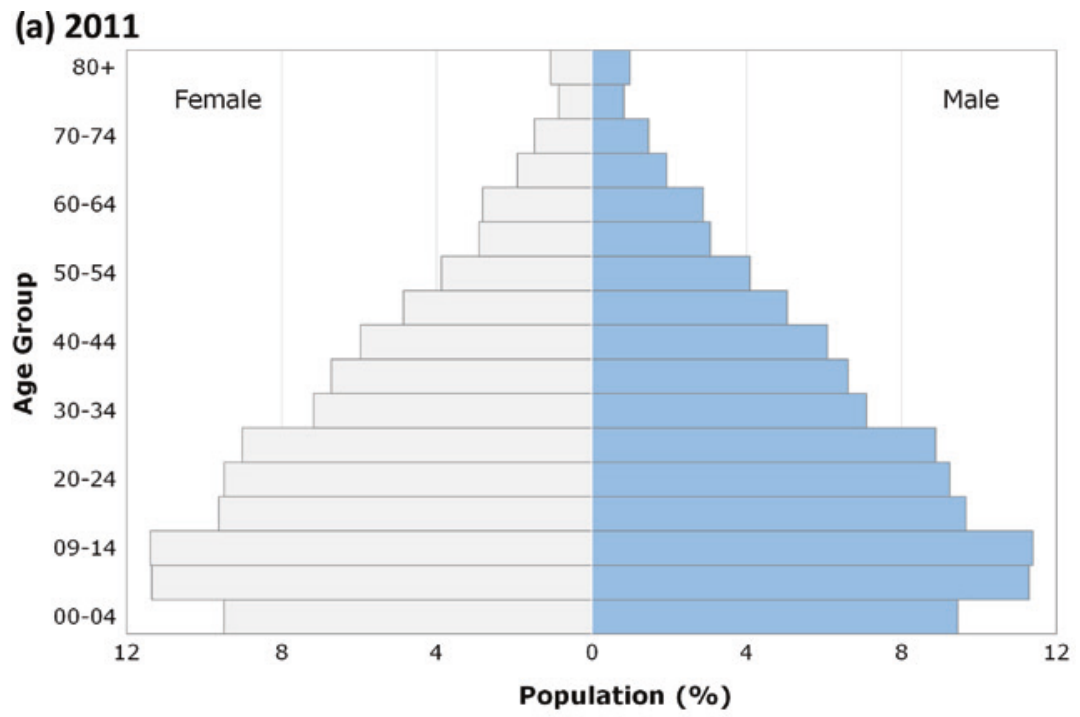

(b) 2050

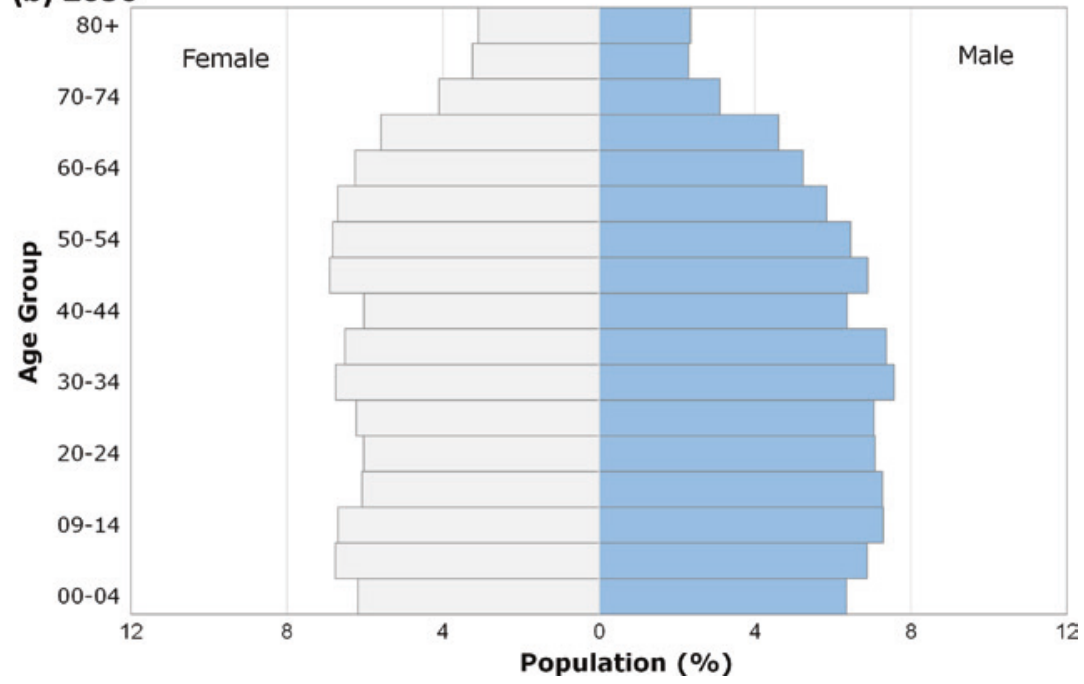

Fig. 7.1 Population pyramids for coastal Bangladesh: a 2011 and $\mathbf{b}$ projected to 2050 (Based on census data from the Bangladesh Bureau of Statistics [2011]) 
on the 2011 census (BBS 2011) is young, although it is visible that the youngest age groups (0-4) are disproportionally small, which reflects recent trends in fertility decline. Compared to the demographic projection for 2050, obtained using the projected method in the Spectrum software, the population structure in the Bangladesh portion of the GBM Delta is displaying an ageing pattern, consistent with increases in life expectancy combined with a decline in number of births.

Over the past quarter-century, the TFR has declined rapidly in many developing countries. Projections typically assume that this trend will continue until replacement level (around 2.1 children per woman) is reached (Bongaarts 2008). Analysis of TFR in Bangladesh shows that TFR declined from 6.7 children per women in 1960 to 2.1 in 2016 (World Bank Data 2018). This decline is evident in both urban and rural areas and across all administrative units, education categories, and wealth quintiles. The 2.0 children per woman in the Bangladesh portion of the GBM Delta reflects this trend. In India, national TFR declined from 5.9 children per women in 1960 to replacement level in 2016 (World Bank Data 2018). TFR in both the Mahanadi and India Bengal (Indian administered section of the GBM Delta) Deltas are even lower, recording 1.7 and 1.5 children per women, respectively (Census of India 2011). Similarly, TFR in Ghana has been continuously decreasing reaching 3.3 children per woman in 2010, while the Volta Delta recorded 3.6 children per woman (GSS 2013).

Increasing life expectancy in these regions is a key component of the demographic transition. For example, average life expectancy in India increased from 59 years in 1991 to over 67.5 years in 2011, representing $14 \%$ gain in 20 years. A similar pattern is observed in Ghana, where male life expectancy increased from 52.6 years in 1984 to 59.4 in 2010 . Females in the country recorded even higher improvement, with life expectancy going from 54.8 years in 1984 to 64.4 years in 2010, resulting in a 17 per cent increase in a 24 -year period. Table 7.1 includes demographic information for the three deltas (one transnational) and the national level indicators for Bangladesh, India and Ghana based on the most recent census. 


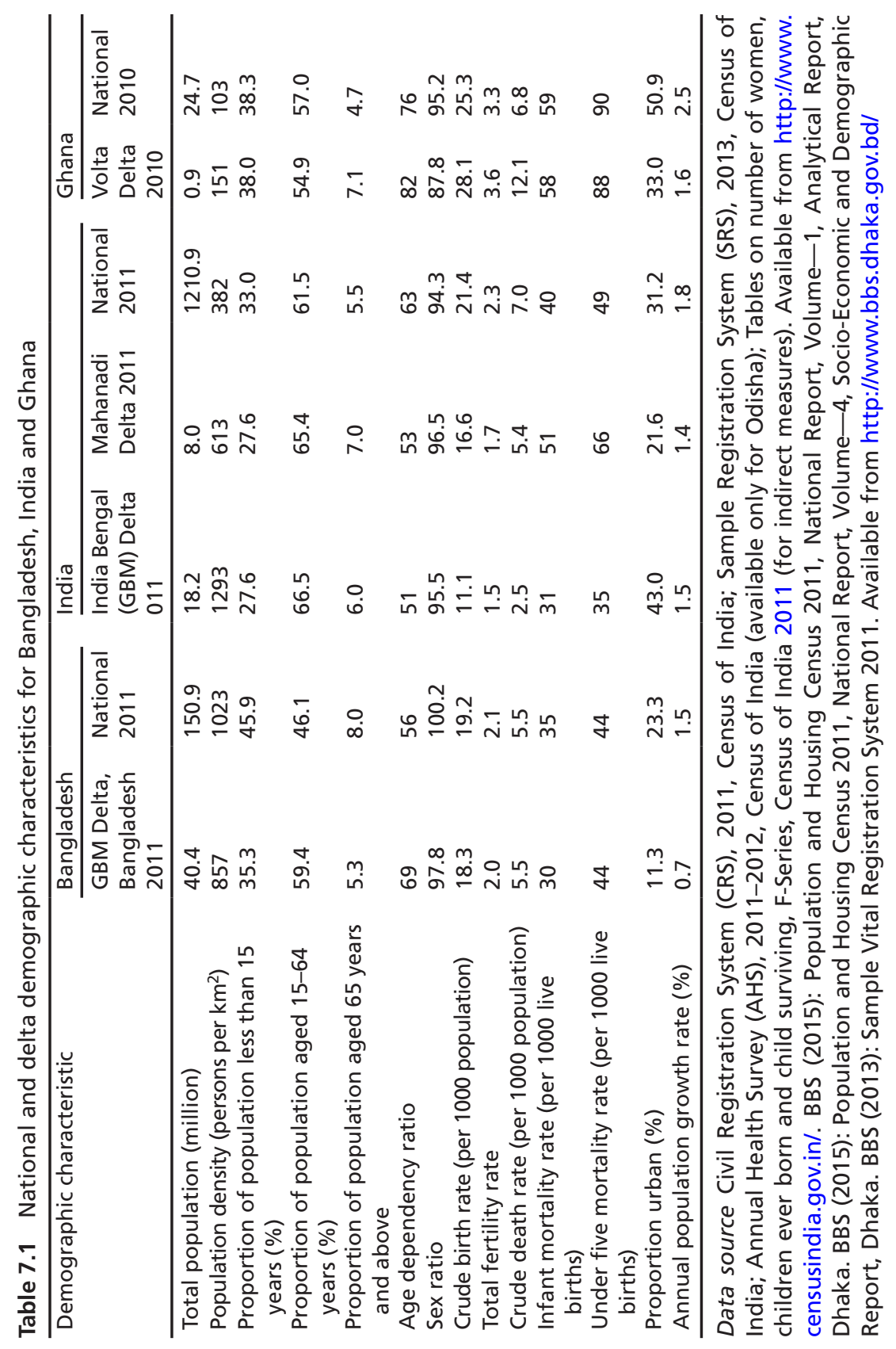




\section{Spatial Variation in Population Driven by Migration Processes}

Environmental challenges result in various types of population movements driven by a wide range of spatio-temporal factors. At the same time, migration is the most challenging component of demographic projection to understand. Households employ different forms of mobility to diversify their portfolio of economic activities through access to distant labour markets in order to ensure survival or to improve their standards of living (Ellis 2000). Migration rates are highest among individuals in age group 21-30 years with secondary or higher education levels: older individuals are typically less inclined to migrate and educated people are more likely to do so (Bernard et al. 2014; Hunter et al. 2015). Gender is an important form of social differentiation that influences migration, played out in different ways across the world (Boyle and Halfacree 2002). Migration intentions and propensity are also manifest in roots in the form of place attachment to where people live (place attachment-Adams 2016) and the perceived benefits from migration (de Jong and Fawcett 1981).

Unequal spatial development, socio-economic transformations and environmental stress are key factors driving ongoing population movement in deltas worldwide (Seto 2011). Deltas are often described as popular destinations for migrants because of diverse socio-economic opportunities associated with fertile soils, freshwater resources and rich biodiversity conducive to rapid agricultural development (Renaud et al. 2013). Such characteristics combine to act as a pull factor attracting migrants to areas that are already densely populated. This rapid consolidation of population has transformed the major global deltas from agrarian economies into industrial and service-driven cities which are projected to continue to act as hubs of attraction to new populations therefore increasing the pressure on delivery of services (Nicholls et al. 2018).

Despite current high rates of urbanisation and the range of factors described above acting as pull factors, net migration rates for the GBM, Mahanadi and Volta Deltas, based on the two most recent censuses for Bangladesh, India and Ghana, reveal contrasting evidence of in-migration as shown in Fig. 7.2. The Bangladeshi GBM Delta is a net sender of migrants to other areas of the country particularly to Dhaka and Chattogram 


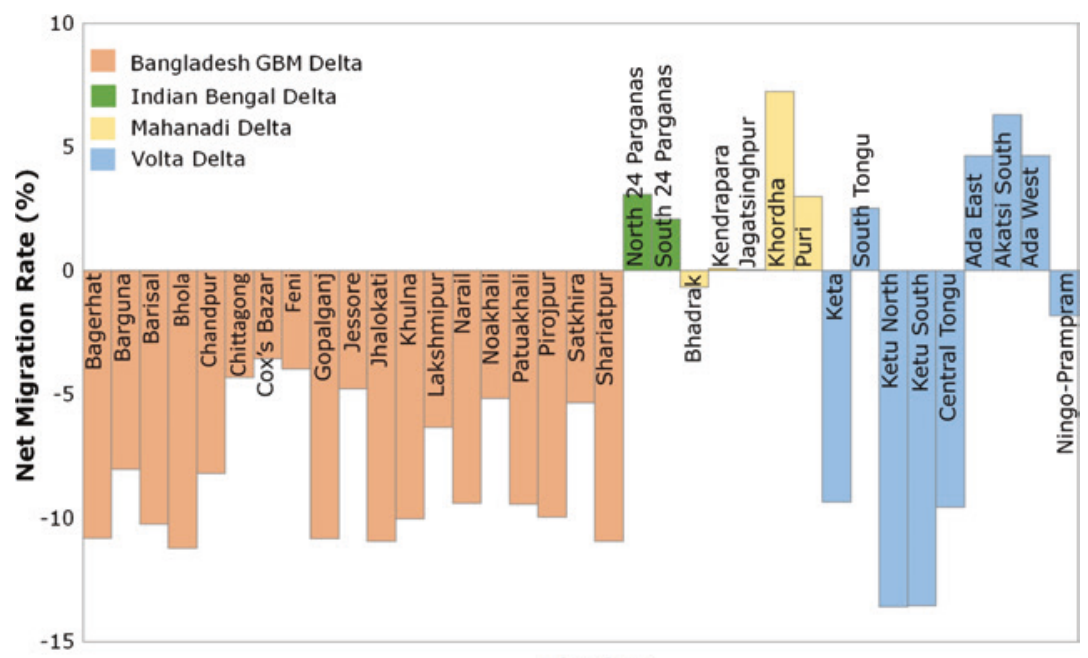

Districts

Fig. 7.2 Net migration rate by delta district in Bangladesh, Ghana and India

(city formerly known as Chittagong) and there is more out-migration of males compared to females. This is similar to the trend recorded in the Mekong Delta, in Vietnam, which has recorded high out-migration rates (Szabo et al. 2016). In addition, all 19 districts located in the Bangladeshi GBM Delta recorded negative net migration. For example, Bhola, an isolated island district, recorded the highest out-migration between 2001 and 2011 (11.2\% of total population); Cox's Bazar recorded the lowest net out-migration for the same period (3.6\% of total population). This net migration is explained in large part by internal migration to the two major urban centres of the country, Dhaka and Chattogram, where employment and access to services are offered in higher proportion compared to rural areas. Dhaka had net annual migration arrivals between 2000 and 2010 of 300-400,000 (te Lintelo et al. 2018), while Chattogram had an aggregate population of 3.3 million in 2001 and four million in 2011 with an annual growth rate of 3.6\% between 1990 and 2011 (Mia et al. 2015). The majority of new arrivals to Chattogram are associated with economic opportunities brought about by rapid industrialisation such as garment manufacture (which is responsible for two-thirds of the growth in employment in Chattogram [Mia et al. 2015]). 
The Volta Delta also has a negative net migration of about 41,000 people over the period 2000-2010, representing $4.8 \%$ of the mid-year population of the area in 2010. The negative net migration in the area is partly as a result of biophysical and development factors such as the construction of the Akosombo Dam in 1964 and the Akuse Dam in 1982, which resulted in significant shoreline recession (Anthony et al. 2016) (see Chapters 4 and 5). Additionally, environmental hazards such as land subsidence, sea-level rise and saltwater intrusion have also impacted the lives of the residents of the Volta Delta (e.g. Appeaning Addo et al. 2018).

In contrast, the Indian Bengal and Mahanadi Deltas are net receivers of migrants. In the former delta, these represent $2.6 \%$ of the mid-year population and are evident in the high proportion of urbanisation (43\% of the total population live in urban areas as shown in Table 7.1). In the Mahanadi Delta, $2.51 \%$ of the total mid-year population are migrants. Figures 7.3 and 7.4 show the direction of migrant flows from both the Indian Bengal and the Mahanadi Deltas. The widths of arrows represent the number of individuals who reported relocating to a different state within the country based on data from a cross-sectional household survey conducted for this research in India in 2016. This reflects that societies tend to become more mobile as the level of development of countries improve; a trend in line with the mobility transition theory postulated by Zelinsky (1971) and examined by, for example, de Haas (2010) and Skeldon (2014). It is relevant to mention that the population movement examined in this section capture long term moves including permanent, seasonal and circular mobility. Previous research shows that empirical evidence on other forms of temporary moves that form the broad spectrum of the mobility continuum such as daily, weekly and occasional movements is more limited (Safra de Campos et al. 2016) and therefore were not included in this research.

\section{Growth of Urban Centres and Impacts of Migration on Rural-Urban Linkages}

Associated with population dynamics and increased mobility is the growth of cities, particularly mega-cities in deltas, with the majority of the global population at present living in urban areas 


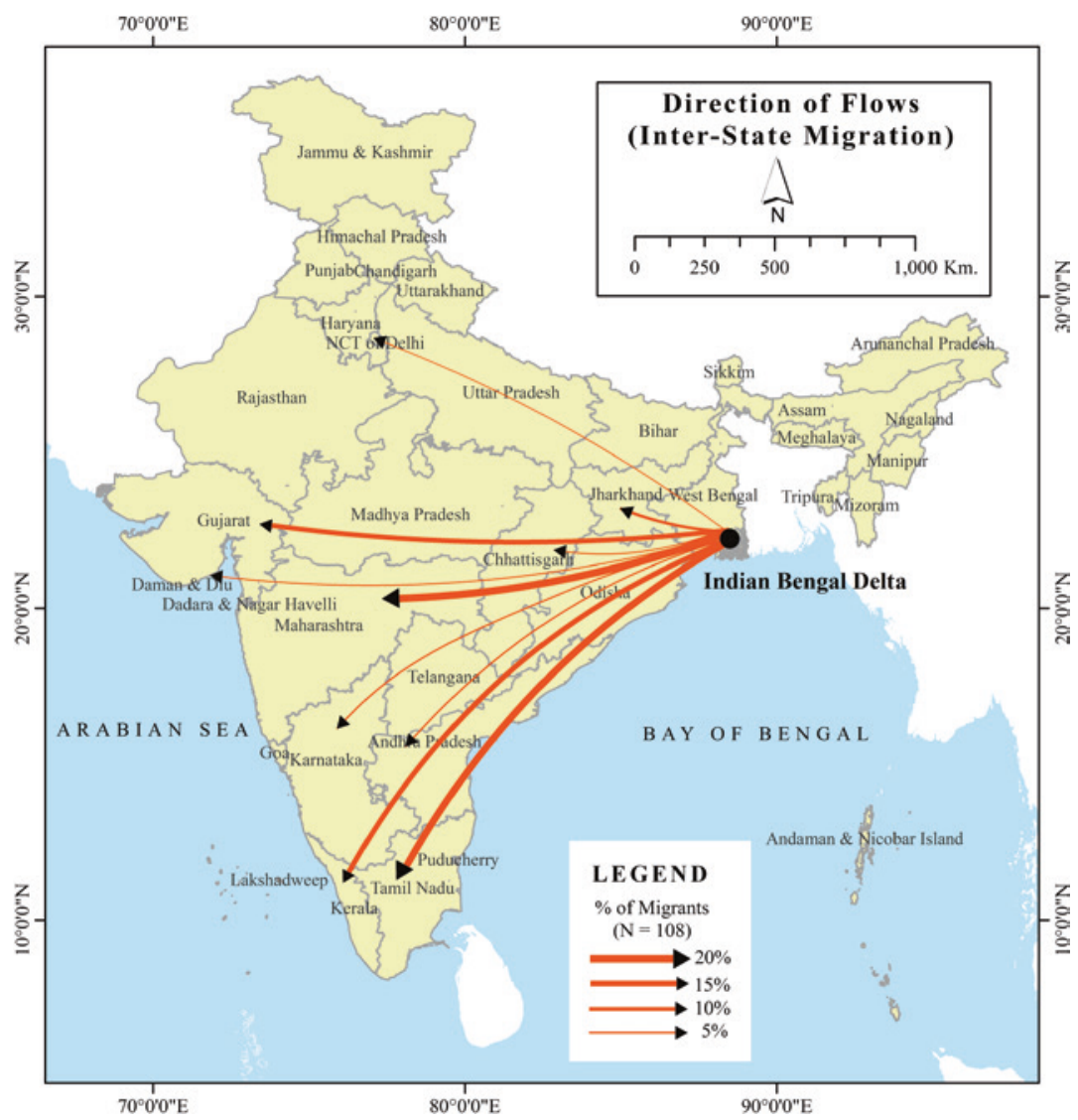

Fig. 7.3 Direction of interstate migration from the Indian section of the GBM Delta, India $(N=108)$

(World Bank Group 2014). Seto (2011) suggests that cities in deltas face two main challenges. First, future urban growth will be more significant in Asia and Africa resulting in additional pressure on existing infrastructure and provision of services. Second, climate change is predicted to increase the frequency and magnitude of extreme events leaving low-lying coastal zones and deltas exposed to the impacts of storm surges, sea-level rise, flooding and coastal erosion (Brown et al. 2018; Nicholls et al. 2018). 


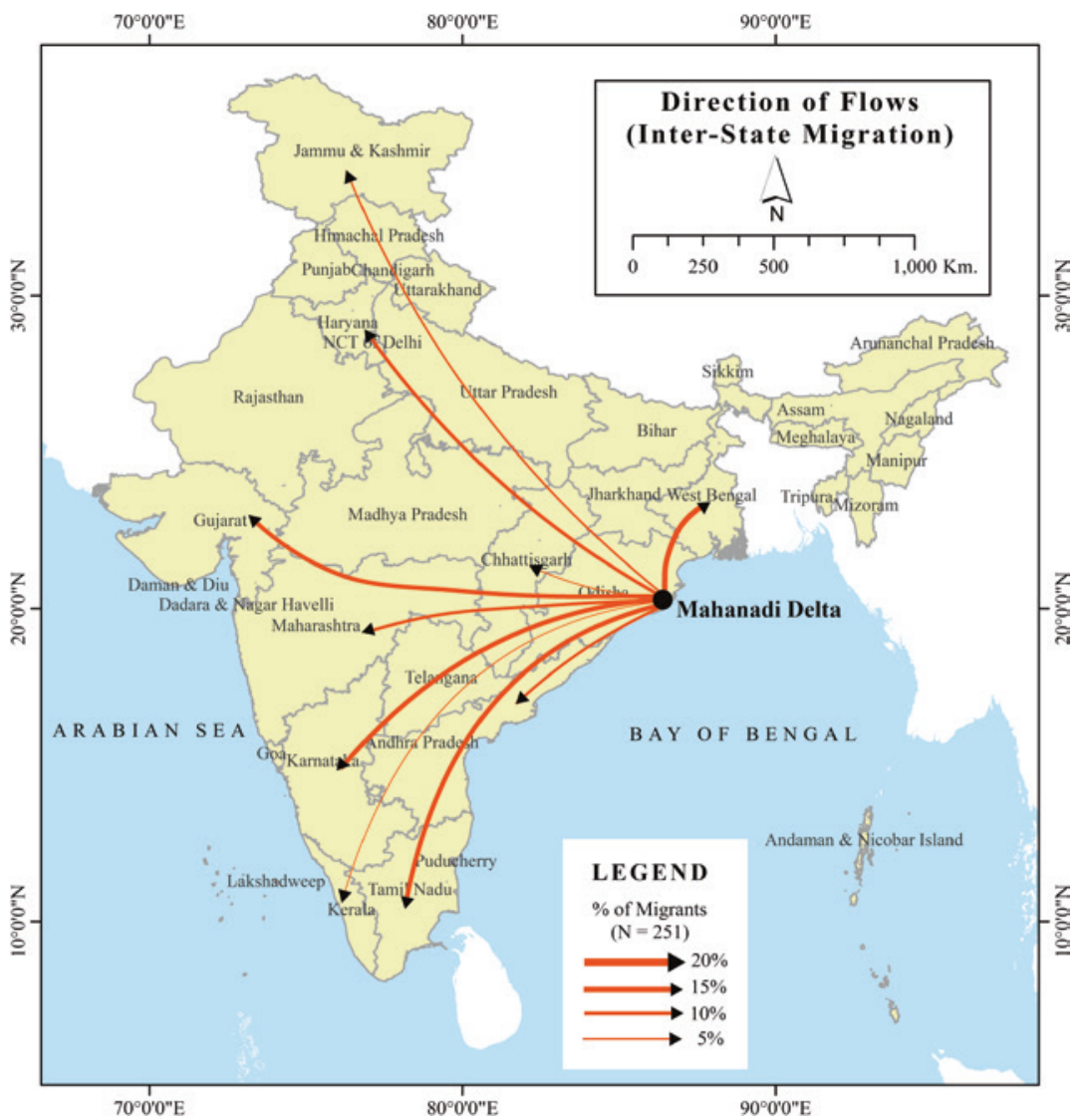

Fig. 7.4 Direction of interstate migration from the Mahanadi Delta, India $(N=251)$

At the same time, deltas are undergoing substantial land-use changes, for example, ports and port-related industries, which have dominated economic and spatial development of many of coastal areas (Dammers et al. 2014). The introduction of alternative ecosystem-based livelihoods including intensive aquaculture has brought about impacts associated with land tenure and livelihood displacement resulting in income loss, food insecurity, rural unemployment and forced migration (Hossain et al. 2013; Amoako-Johnson et al. 2016). 
In addition to the socio-economic and environmental challenges, there are other dimensions associated with rapid urbanisation. Population movements are often associated with unequal development and distribution of resources (Tacoli and Mabala 2010). However, the flow of remittances between urban and rural areas is an important and stable economic resource that supports communities in rural areas. The importance of remittances for the domestic economy of households in deltas was captured in the household survey conducted in Bangladesh, Ghana and India. Across these three deltas, 66\% of respondents reported receiving remittances. The vast majority of respondents used this income mainly to help pay for food, health, education, debt repayment and household appliances. This supports widespread evidence that remittances sent by migrants have the potential to enable rural households to overcome credit and risk constraints by spatial diversification of labour and income (Stark 1991). Moreover, if invested in modern agricultural technologies, tools and livestock, subsistence farmers can increase their productivity and complete the transition from familial to commercial production, which is instrumental in the diversification of rural economies (Webber and Barnett 2010).

In addition to financial benefits derived from remittance income, migration also circulates new ideas, knowledge, skills and technologies from destination to origin areas (Levitt and Lamba-Nieves 2011). This rural-urban linkage through social remittances was also expressed in the same survey; $75 \%$ of households reported benefits from new ideas and knowledge to build adaptive capacities at the origin.

\subsection{Environmental Stress: Trigger for Migration?}

Deltas and low-lying coastal areas are at risk from sea-level rise and storm surges which may result in submergence of seafront settlements and increased flooding of coastal land, as well as saltwater intrusion of surface waters and groundwater (Nicholls and Cazenave 2010; Brown et al. 2018). Changes in the intensity and frequency of cyclones and 
persistent variance in pluviometry are also a likely consequence of climate change. Flooding in low-lying densely populated coastal areas is predominantly seasonal and usually short-lived, yet it can have significant impacts on vulnerable sections of society. For example, poor households living in flood prone areas might become displaced and forced to move temporarily seeking access to frontline services and alternative forms of livelihood. Furthermore, there might be instances where impacted communities must be relocated permanently. Due to the characteristics described above, it is tempting to suggest that existing or future environmental factors are influential in driving individual decisions on migration, more so in already vulnerable locations in low-lying coastal areas. The cross-sectional survey of 5479 households across the delta locations in India, Ghana and Bangladesh revealed that more than $30 \%$ of these representative households reported at least one migrant. The survey collected data on the motivation for migration by one or more household members: eliciting all relevant motivations for migration and ranking them to ascertain the main driver reported by household heads. Figure 7.5 shows that only $2.8 \%$ of respondents perceived the main reason behind the decision to move to have been associated with environmental stress. The majority of respondents perceived economic and social factors to have accounted for the migration of their household members.

The results reveal that few people, even in places significantly exposed to environmental hazards and climate variability, self-report as environmental migrants. Yet environmental risks may still play a significant role in migration decisions at the household level (Abu et al. 2014). In the aforementioned survey, households in coastal Ghana, India and Bangladesh also reported significant exposure to environmental risks and perceived economic insecurity associated with environmental hazards. One-third of all respondents perceived that there was an increased exposure to hazards including cyclone, drought, erosion, flooding, salinity and storm surge over the previous five years. Over one-third of respondents $(37.5 \%)$ also reported the environment to be more hazardous and extreme events to be more frequent. Similarly, between 


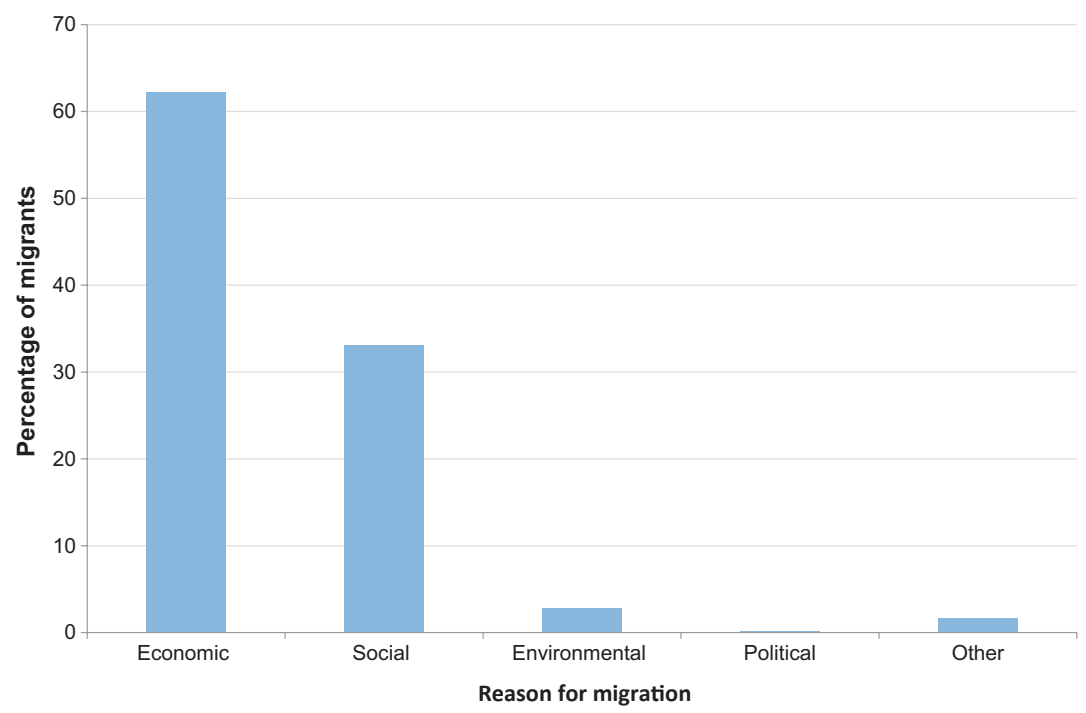

Fig. 7.5 Main reason for migration across the three deltas $(N=2310)$ : economic (employment and debt); social (education, marriage, health, family and housing problems); environmental (loss of income for one/multiple seasons, environmental degradation and extreme events); political (social/political problems)

40 and $80 \%$ of the respondents associated environmental factors with more insecure livelihoods. These perceptions of underlying environmental degradation and insecurity suggest a correlation with migration of household members.

Analysis also recognised the diversity of environmental stressors, categorising these as either rapid- or slow-onset, each potentially affecting migration in different forms (Warner 2010) with links being made between migration and thresholds associated with access to various forms of capital assets, and changes in land use and livelihood (McLeman 2018b). This shows that the role played by mobility as a response to climate events depends heavily on the duration, intensity and nature of the stimulus, as well as the composition and assets of households, their previous experience, the networks to which they belong, and the adaptation responses set in motion (see Chapter 9). 


\subsection{Migrate, Relocate or Remain: Policy and Interventions in Deltas}

The Anthropocene trend of increased human mobility may well be intensified by the effects of climate change, displacement often being one of the consequences associated with environmental change. Displacement due to climate and environmental hazards is common throughout the world, with estimates of over 18 million people impacted by weather-related events, including 8.6 million people displaced by floods and 7.5 million by storms, with hundreds of millions more at risk (iDMC 2018). Resulting movements are often temporary and short-lived, with the majority of the people impacted returning to their place of origin. This involuntary and unforeseen movement of people from their place of residence due to extreme weatherrelated impacts on property and infrastructure poses a challenge for policy-makers and practitioners. Therefore, based on analysis of demographic changes, governance processes have agency in planning for different forms of mobility through creating favourable conditions for voluntary movement as well as prepare for planned relocation alternatives (Adger et al. 2018).

Planned relocation, also termed resettlement or managed retreat, is a structured form of response in the face of sea-level rise or other environmental hazards affecting the lives, livelihood and property (see Chapter 2, Wong et al. 2014; Hino et al. 2017; Mortreux et al. 2018). Relocation is typically initiated, supervised and implemented from national to local level and develops from small communities, but it may also involve large populations (Hino et al. 2017). The strategic relocation of structures and vulnerable communities coupled with the abandonment of land to manage natural hazard risk is a potential adaptation in low-lying zones exposed to the impacts of coastal hazards but has been instigated with varying degrees of success (Hino et al. 2017). In addition to implementation costs, planned relocation initiatives result in a range of cultural, social and psychological losses related to disruptions to sense of place and identity, self-efficacy, and rights to ancestral land and culture (McNamara et al. 2018). Those involved in these processes in coastal areas in Ghana speak for themselves on those social and cultural dimensions of relocation in Box 7.1. 
There are significant challenges to governments of enacting fair process and providing frontline services for growing urban populations. Initiatives that seek to enhance the rights of the internally displaced as a direct result of change and empower and protect these populations are being discussed in both policy and academic circles. The legitimacy and efficacy of each individual strategy depends on upholding the principle of fairness of process and ultimately respect for the autonomy of individuals and their decisions of where and how they live (Warner et al. 2013).

\section{Box 7.1 Qualitative interviews with residents in the Volta Delta on diverse impacts on resettlement in coastal villages in Ghana}

1. "Resettlement is an expensive exercise. Actually, there is another sea defence going on at Ada. So government is no more waiting for disaster to happen before they reclaim the land (...) when it's coming (a disaster), we see early, then we claim when it's coming". (Quantity surveyor, Public Works Department)

2. "The other problem some of us have seen in that place is that previously they are closer to the beach for their fishing activities but now it is a distance away from the beach. Now you have to walk a distance unlike previously. That is the only thing and the boulders that they packed over there, if they want to drag the net that is also a small problem over there". (Planning officer, Keta Municipal Assembly)

3. "We are fishermen here so any resettlement consideration must not be far from the sea. We will continue to be fishers because that is the work we know how to do well and depend on to cater for our kids, the place must not be too far from the sea. In addition; since we have children, there must be a school in the place. Every human being will definitely fall sick so there must be a hospital at the place. Once we go fishing, we need to sell the catch so there must be a market as well. All those things must be provided at the new location before any resettlement. But if the four aforementioned facilities are not provided; i.e. the place is not close to the sea, no school for our kids to attend, no market for our wives to trade and hospital for us to get health care when we are ill then it will be difficult for us to agree to a resettlement to any such location". (Focus group male participant from a community affected by sea erosion)

4. "We are comfortable here. If the community is secure we are comfortable here. Due to livelihood, employment and so on and so forth we are comfortable here. We can get work to do and the community being secured, we can live here and everything will be okay with us". (Male chief fisherman of a resettled community) 


\subsection{Conclusion}

The Anthropocene is marked by changes that occur at different scales and speeds. Delta communities worldwide, particularly in the developing world, are exposed to major uncertainties to their socio-ecological systems with an element of control for only some risks. The interaction between multiple socio-economic and biophysical changes at different geographical scales and speeds interact to produce uneven outcomes for people's lives and livelihoods in locations exposed to the impacts of this interrelation. As governments design and invest in protective measures and wider coastal development policies, strategies will have major implications for continued settlement of high-risk locations. Current and future migration flows in deltas involve movement of people from unprotected settlements displaced by the slow and continuous loss of productive land due to slow onset processes such as sea-level rise, punctuated by periodic surges of migrants in the aftermath of extreme storm events (McLeman 2018a).

Continued growth of delta urban settlements in itself generates challenges of social cohesion, dependence on hinterlands and population stagnation in non-metropolitan areas. The destinations for migrants are often predictable: existing social networks, historical linkages and economic opportunities tend to be the main pull factors between origin and destination areas. Migration affects social cohesion in destination settlements and communities (Benson and O'Reilly 2009; Skeldon 2014): New migrant populations can feel dislocated from norms and cultures in destination areas, while a strong sense of attachment to communities of origin is shown to strengthen intra-community ties.

Social and environmental change in deltas has the significant potential to disrupt migration flows and individual migration decisions in deltaic areas worldwide (Call et al. 2017). Migratory systems can be altered in multiple ways, ranging from temporary displacement from weather-related disasters to long term decline of regions resulting in planned relocation or managed retreat initiatives. The demographic dimensions of where people live and move in deltas demonstrate how socio-economic transformation and climate change are intertwined with 
the political economy of development processes. Migration is a successful and desirable option for many people, availing themselves of better lives and opportunities. It is a reality of life in deltas. In effect, it is suggested that the sustainability of delta cities is dependent on the effectiveness and speed of integration of new migrant populations into the social and political life of these places. Investment in the future of cities involves people and place-making as much as infrastructure.

\section{References}

Abel, G. J., Barakat, B., Kc, S., \& Lutz, W. (2016). Meeting the sustainable development goals leads to lower world population growth. Proceedings of the National Academy of Sciences, 113(50), 14294-14299. https://doi. org/10.1073/pnas.1611386113.

Abu, M., Codjoe, S. N. A., \& Sward, J. (2014). Climate change and internal migration intentions in the forest-savannah transition zone of Ghana. Population and Environment, 35(4), 341-364. https://doi.org/10.1007/ s11111-013-0191-y.

Adams, H. (2016). Why populations persist: Mobility, place attachment and climate change. Population and Environment, 37(4), 429-448. https://doi. org/10.1007/s11111-015-0246-3.

Adger, W. N., Safra de Campos, R., \& Mortreux, C. (2018). Mobility, displacement and migration, and their interactions with vulnerability and adaptation to environmental risks. In R. McLeman \& F. Gemenne (Eds.), Routledge handbook of environmental displacement and migration (pp. 29-41). London, UK: Routledge.

Amoako-Johnson, F., Hutton, C. W., Hornby, D., Lázár, A. N., \& Mukhopadhyay, A. (2016). Is shrimp farming a successful adaptation to salinity intrusion? A geospatial associative analysis of poverty in the populous Ganges-Brahmaputra-Meghna Delta of Bangladesh. Sustainability Science, 11(3), 423-439. https://doi.org/10.1007/s11625-016-0356-6.

Anthony, E. J., Almar, R., \& Aagaard, T. (2016). Recent shoreline changes in the Volta River Delta, West Africa: The roles of natural processes and human impacts. African Journal of Aquatic Science, 41(1), 81-87. https:// doi.org/10.2989/16085914.2015.1115751. 
Appeaning Addo, K., Nicholls, R. J., Codjoe, S. N. A., \& Abu, M. (2018). A biophysical and socioeconomic review of the Volta Delta, Ghana. Journal of Coastal Research, 34(5), 1216-1226. http://dx.doi.org/10.2112/ JCOASTRES-D-17-00129.1.

BBS. (2011). Population and housing census 2011. Bangladesh Bureau of Statistics (BBS), Ministry of Planning, Government of the People's Republic of Bangladesh, Dhaka, Bangladesh. http://www.bbs.dhaka.gov.bd. Last accessed 12 November 2018.

Benson, M., \& O’Reilly, K. (2009). Migration and the search for a better way of life: A critical exploration of lifestyle migration. The Sociological Review, 57(4), 608-625. https://doi.org/10.1111/j.1467-954X.2009.01864.x.

Bernard, A., Bell, M., \& Charles-Edwards, E. (2014). Life-course transitions and the age profile of internal migration. Population and Development Review, 40(2), 213-239. https://doi.org/10.1111/j.1728-4457.2014.00671.x.

Bongaarts, J. (2008). Fertility transitions in developing countries: Progress or stagnation? Studies in Family Planning, 39(2), 105-110. https://doi. org/10.1111/j.1728-4465.2008.00157.x.

Boyle, P., \& Halfacree, K. (Eds.). (2002). Migration and gender in the developed world. London, UK: Routledge.

Brown, S., Nicholls, R. J., Lázár, A. N., Hornby, D. D., Hill, C., Hazra, S., et al. (2018). What are the implications of sea-level rise for a 1.5, 2 and $3{ }^{\circ} \mathrm{C}$ rise in global mean temperatures in the Ganges-Brahmaputra-Meghna and other vulnerable deltas? Regional Environmental Change, 18(6), 1829-1842. http://dx.doi.org/10.1007/s10113-018-1311-0.

Caldwell, J. C. (2006). Demographic theory: A long view. In J. C. Caldwell (Ed.), Demographic transition theory (pp. 301-320). Dordrecht, The Netherlands: Springer.

Call, M. A., Gray, C., Yunus, M., \& Emch, M. (2017). Disruption, not displacement: Environmental variability and temporary migration in Bangladesh. Global Environmental Change, 46, 157-165. https://doi. org/10.1016/j.gloenvcha.2017.08.008.

Census of India. (2011). Fertility data. Office of the Registrar General and Census Commissioner, Government of India. http://censusindia.gov.in/. Last accessed 12 November 2018.

Dammers, E., Bregt, A. K., Edelenbos, J., Meyer, H., \& Pel, B. (2014). Urbanized deltas as complex adaptive systems: Implications for planning and design. Built Environment, 40(2), 156-168. 
de Haas, H. (2010). Migration and development: A theoretical perspective. International Migration Review, 44(1), 227-264. https://doi. org/10.1111/j.1747-7379.2009.00804.x.

de Jong, G. F., \& Fawcett, J. T. (1981). Motivations for migration: An assessment and a value-expectancy research model. In G. F. De Jong \& R. W. Gardner (Eds.), Migration decision making: Multidisciplinary approaches to microlevel studies in developed and developing countries. New York, NY: Pergamon.

Dyson, T. (2013). On demographic and democratic transitions. Population and Development Review, 38(s1), 83-102. https://doi.org/10.1111/j.17284457.2013.00553.x.

Ellis, F. (2000). Rural livelihoods and diversity in developing countries. Oxford, UK: Oxford University Press.

Ericson, J. P., Vörösmarty, C. J., Dingman, S. L., Ward, L. G., \& Meybeck, M. (2006). Effective sea-level rise and deltas: Causes of change and human dimension implications. Global and Planetary Change, 50(1-2), 63-82. https://doi.org/10.1016/j.gloplacha.2005.07.004.

GSS. (2013). National analytical report: 2010 Population and housing census. Accra, Ghana: Ghana Statistical Service. http://www.statsghana.gov. gh/docfiles/publications/2010_PHC_National_Analytical_Report.pdf. Last accessed 28 August 2018.

Hino, M., Field, C. B., \& Mach, K. J. (2017). Managed retreat as a response to natural hazard risk. Nature Climate Change, 7(5), 364. http://dx.doi. org/10.1038/nclimate3252.

Hossain, M. S., Uddin, M. J., \& Fakhruddin, A. N. M. (2013). Impacts of shrimp farming on the coastal environment of Bangladesh and approach for management. Reviews in Environmental Science and Bio/Technology, 12(3), 313-332. https://doi.org/10.1007/s11157-013-9311-5.

Hunter, L. M., Luna, J. K., \& Norton, R. M. (2015). Environmental dimensions of migration. Annual Review of Sociology, 41(1), 377-397. https://doi. org/10.1146/annurev-soc-073014-112223.

iDMC. (2018). GRID 2018: Global report on internal displacement. Geneva, Switzerland: Internal Displacement Monitoring Centre. http:// www.internal-displacement.org/sites/default/files/publications/documents/2018-GRID.pdf. Last accessed 12 November 2018.

Levitt, P., \& Lamba-Nieves, D. (2011). Social remittances revisited. Journal of Ethnic and Migration Studies, 37(1), 1-22. https://doi.org/10.1080/13691 83X.2011.521361. 
Lutz, W., Butz, W. P., \& Samir, K. E. (Eds.). (2017). World population and human capital in the twenty-first century: An overview. Oxford, UK: Oxford University Press.

McLeman, R. (2018a). Migration and displacement risks due to mean sea-level rise. Bulletin of the Atomic Scientists, 74(3), 148-154. http://dx.doi.org/10.1 080/00963402.2018.1461951.

McLeman, R. (2018b). Thresholds in climate migration. Population and Environment, 39(4), 319-338. http://dx.doi.org/10.1007/s11111-017-0290-2. McMichael, A. J. (2014). Population health in the Anthropocene: Gains, losses and emerging trends. The Anthropocene Review, 1(1), 44-56. https://doi. org/10.1177/2053019613514035.

McNamara, K. E., Bronen, R., Fernando, N., \& Klepp, S. (2018). The complex decision-making of climate-induced relocation: Adaptation and loss and damage. Climate Policy, 18(1), 111-117. https://doi.org/10.1080/146 93062.2016 .1248886$.

Mia, M. A., Nasrin, S., Zhang, M., \& Rasiah, R. (2015). Chittagong, Bangladesh. Cities, 48, 31-41. https://doi.org/10.1016/j.cities.2015.05.011.

Mortreux, C., Safra de Campos, R., Adger, W. N., Ghosh, T., Das, S., Adams, H., et al. (2018). Political economy of planned relocation: A model of action and inaction in government responses. Global Environmental Change, 50, 123-132. http://dx.doi.org/10.1016/j.gloenvcha.2018.03.008.

Nicholls, R. J., Brown, S., Goodwin, P., Wahl, T., Lowe, J., Solan, M., et al. (2018). Stabilization of global temperature at $1.5^{\circ} \mathrm{C}$ and $2.0^{\circ} \mathrm{C}$ : Implications for coastal areas. Philosophical Transactions of the Royal Society, 376(2119). http://dx.doi.org/10.1098/rsta.2016.0448.

Nicholls, R. J., \& Cazenave, A. (2010). Sea-level rise and its impact on coastal zones. Science, 328(5985), 1517. http://dx.doi.org/10.1126/science.1185782.

Renaud, F. G., Syvitski, J. P. M., Sebesvari, Z., Werners, S. E., Kremer, H., Kuenzer, C., et al. (2013). Tipping from the Holocene to the Anthropocene: How threatened are major world deltas? Current Opinion in Environmental Sustainability, 5(6), 644-654. http://dx.doi.org/10.1016/j. cosust.2013.11.007.

Safra de Campos, R., Bell, M., \& Charles-Edwards, E. (2016). Collecting and analysing data on climate-related local mobility: The MISTIC Toolkit. Population, Space and Place, 23(6), e2037. http://dx.doi.org/10.1002/psp.2037.

Samir, K., \& Lutz, W. (2017). The human core of the shared socioeconomic pathways: Population scenarios by age, sex and level of education for all countries to 2100. Global Environmental Change, 42, 181-192. https://doi. org/10.1016/j.gloenvcha.2014.06.004. 
Seto, K. C. (2011). Exploring the dynamics of migration to mega-delta cities in Asia and Africa: Contemporary drivers and future scenarios. Global Environmental Change, 21, S94-S107. https://doi.org/10.1016/j. gloenvcha.2011.08.005.

Seto, K. C., Güneralp, B., \& Hutyra, L. R. (2012). Global forecasts of urban expansion to 2030 and direct impacts on biodiversity and carbon pools. Proceedings of the National Academy of Sciences, 109(40), 16083. http://dx. doi.org/10.1073/pnas.1211658109.

Skeldon, R. (2014). Migration and development: A global perspective (Originally published 1997). London, UK: Routledge.

Stark, O. (1991). Migration in LDCs: Risk, remittances, and the family. Finance and Development, 28(4), 39.

Szabo, S., Adger, W. N., \& Matthews, Z. (2018). Home is where the money goes: Migration-related urban-rural integration in delta regions. Migration and Development, 7(2), 163-179. https://doi.org/10.1080/21632324.2017. 1374506.

Szabo, S., Brondizio, E., Renaud, F. G., Hetrick, S., Nicholls, R. J., Matthews, Z., et al. (2016). Population dynamics, delta vulnerability and environmental change: Comparison of the Mekong, Ganges-Brahmaputra and Amazon delta regions. Sustainability Science, 11(4), 539-554. http://dx.doi. org/10.1007/s11625-016-0372-6.

Tacoli, C., \& Mabala, R. (2010). Exploring mobility and migration in the context of rural-Urban linkages: Why gender and generation matter. Environment and Urbanization, 22(2), 389-395. https://doi. org/10.1177/0956247810379935.

te Lintelo, D. J. H., Gupte, J., McGregor, J. A., Lakshman, R., \& Jahan, F. (2018). Wellbeing and urban governance: Who fails, survives or thrives in informal settlements in Bangladeshi cities? Cities, 72, 391-402. https://doi. org/10.1016/j.cities.2017.10.002.

Warner, K. (2010). Global environmental change and migration: Governance challenges. Global Environmental Change, 20(3), 402-413. https://doi. org/10.1016/j.gloenvcha.2009.12.001.

Warner, K., Afifi, T., Kalin, W., Leckie, S., Ferris, B., Martin, S. F., et al. (2013). Changing climate, moving people: Framing migration, displacement and planned relocation. UNU-EHS Publication Series, Policy Brief 8. Tokyo, Japan: United Nations University.

Webber, M., \& Barnett, J. (2010). Accommodating migration to promote adaptation to climate change. Washington, DC: The World Bank. 
Whitmee, S., Haines, A., Beyrer, C., Boltz, F., Capon, A. G., de Souza Dias, B. F., et al. (2015). Safeguarding human health in the Anthropocene epoch: Report of The Rockefeller Foundation, Lancet Commission on planetary health. The Lancet, 386(10007), 1973-2028. http://dx.doi.org/10.1016/ S0140-6736(15)60901-1.

Wong, P. P., Losada, I. J., Gattuso, J.-P., Hinkel, J., Khattabi, A., McInnes, K. L., et al. (2014). Coastal systems and low-lying areas. In C. B. Field, V. R. Barros, D. J. Dokken, K. J. Mach, M. D. Mastrandrea, T. E. Bilir, M. Chatterjee, K. L. Ebi, Y. O. Estrada, R. C. Genova, B. Girma, E. S. Kissel, A. N. Levy, S. MacCracken, P. R. Mastrandrea, \& L. L. White (Eds.), Climate change 2014: Impacts, adaptation, and vulnerability. Part A: Global and sectoral aspects (pp. 361-409). Contribution of Working Group II to the fifth Assessment Report of the Intergovernmental Panel on Climate Change. Cambridge, UK and New York, NY: Cambridge University Press.

World Bank Data. (2018). Fertility rate (Bangladesh). https://data.worldbank. org/indicator/SP.DYN.TFRT.IN. Last accessed 26 October 2018.

World Bank Group. (2014). World development indicators 2014. World Bank Publications. https://data.worldbank.org/products/wdi. Last accessed 9 September 2018.

Zelinsky, W. (1971). The hypothesis of the mobility transition. Geographical Review, 61, 219-249. https://doi.org/10.2307/213996. 
Open Access This chapter is licensed under the terms of the Creative Commons Attribution 4.0 International License (http://creativecommons. org/licenses/by/4.0/), which permits use, sharing, adaptation, distribution and reproduction in any medium or format, as long as you give appropriate credit to the original author(s) and the source, provide a link to the Creative Commons license and indicate if changes were made.

The images or other third party material in this chapter are included in the chapter's Creative Commons license, unless indicated otherwise in a credit line to the material. If material is not included in the chapter's Creative Commons license and your intended use is not permitted by statutory regulation or exceeds the permitted use, you will need to obtain permission directly from the copyright holder.

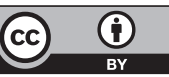

